\title{
Intracellular ATP Signaling Contributes to FAM3A-Induced PDX1 Upregulation in Pancreatic Beta Cells
}

\section{()(1) $\Theta \Theta$}

Authors

Han Yan', Zhenzhen Chen², Haizeng Zhang², Weili Yang1, 3, Xiangyang Liu1, Yuhong Meng1, Rui Xiang1, Zhe Wu4, Jingjing $\mathrm{Ye}^{5}$, Yujing $\mathrm{Chi}^{5}{ }^{\mathbb{D}}$, Jichun Yang ${ }^{1}$

\section{Affiliations}

1 Department of Physiology and Pathophysiology, School of Basic Medical Sciences, Key Laboratory of Molecular Cardiovascular Science of the Ministry of Education, Center for Non-coding RNA Medicine, Peking University Health Science Center, Beijing 100191, China

2 Hypertension Center, Fuwai Hospital, Chinese Academy of Medical Sciences and Peking Union Medical College, State Key Laboratory of Cardiovascular Disease, National Center for Cardiovascular Diseases, Beijing 100037, China

3 Beijing Key Laboratory of Diabetes Research and Care, Beijing Tongren Hospital, Capital Medical University, Beijing 100730, China

4 Department of Gastroenterology, Peking University People's Hospital, Beijing 100044, China

5 Department of Central Laboratory \& Institute of Clinical Molecular Biology, Peking University People's Hospital, Beijing 100044, China

Key words

FAM3A, pancreatic $\beta$ cells, intracellular ATP, PDX1, insulin secretion

received 11.04 .2021

revised 22.07.2021

accepted $\quad 03.08 .2021$

published online 30.09 .2021

Bibliography

Exp Clin Endocrinol Diabetes 2022; 130: 498-508

DOI 10.1055/a-1608-0607

ISSN 0947-7349

(C) 2021. The Author(s).

This is an open access article published by Thieme under the terms of the Creative Commons Attribution-NonDerivative-NonCommercial-License, permitting copying and reproduction so long as the original work is given appropriate credit. Contents may not be used for commercial purposes, or adapted, remixed, transformed or built upon. (https://creativecommons. org/licenses/by-nc-nd/4.0/)

Georg Thieme Verlag, Rüdigerstraße 14,

70469 Stuttgart, Germany
Correspondence

Yujing Chi, Ph.D

Department of Central Laboratory \& Institute of Clinical Molecular Biology, Peking University People’s Hospital 100044 Beijing

China

Tel.: (+ 86) 10-88324377

chiyujing@bjmu.edu.cn

Supplementary Material is available under https://doi.org/10.1055/a-1608-0607

\begin{abstract}
FAM3A is a recently identified mitochondrial protein that stimulates pancreatic-duodenal homeobox 1 (PDX1) and insulin expressions by promoting ATP release in islet $\beta$ cells. In this study, the role of intracellular ATP in FAM3A-induced PDX1 expression in pancreatic $\beta$ cells was further examined. Acute FAM3A inhibition using siRNA transfection in mouse pancreatic islets significantly reduced PDX1 expression, impaired insulin secretion, and caused glucose intolerance in normal mice. In vitro, FAM3A overexpression elevated both intracellular and extracellular ATP contents and promoted PDX1 expression and insulin secretion. FAM3A-induced increase in cellular calcium $\left(\mathrm{Ca}^{2+}\right)$ levels, PDX1 expression, and insulin secretion, while these were significantly repressed by inhibitors of $\mathrm{P} 2$ receptors or the L-type $\mathrm{Ca}^{2+}$ channels. FAM3A-induced PDX1 expression was abolished by a calmodulin inhibitor. Likewise, FAM3A-induced $\beta$-cell proliferation was also inhibited by a $\mathrm{P} 2$ receptor inhibitor and an L-type $\mathrm{Ca}^{2+}$ channels inhibitor. Both intracellular and extracellular ATP contributed to FAM3A-induced PDX1 expression, insulin secretion, and proliferation of pancreatic $\beta$ cells.
\end{abstract}




\section{Introduction}

Diabetes mellitus (DM) is mainly characterized by chronic hyperglycemia. The number of DM patients is expected to reach 642 million by 2040 [1]. Generally, DM is caused by a relative or absolute deficiency of insulin secretion. Pancreatic $\beta$-cell dysregulation has been identified as a major factor contributing to insufficient insulin secretion. In the pathogenesis of DM, chronic exposure to high concentrations of glucose and free fatty acids can lead to oxidative stress [2], inflammation [3], autophagy [4], and senescence [5], all of which contribute to pancreatic $\beta$-cell dysfunction and death.

Reduction of ATP synthesis is the key feature of mitochondrial dysfunction, which is the core event causing $\beta$-cell dysfunction and diabetes. Both intracellular and extracellular ATP regulates $\beta$-cell functions. The increase in intracellular ATP/ADP ratio leads to the closure of ATP-sensitive potassium $\left(\mathrm{K}^{+}\right)$channels and opening of L-type calcium $\left(\mathrm{Ca}^{2+}\right)$ channels, resulting in an increase in intracellular free $\mathrm{Ca}^{2+}$ concentration and triggering of exocytosis of insulin secretory granules [6]. In diabetic islets, the ATP content was noted to be significantly lower than that in normal islets. Likewise, lipid stress was found to activate uncoupling protein 2 (UCP2) expression in pancreatic $\beta$ cells and impair ATP synthesis, which could eventually lead to insulin secretion disorders [7]. Insulin secretory dysfunction caused by glucose and lipid overloads is negatively correlated with ATP synthesis [8, 9]. The expression of ATP synthase $\beta$ subunit (ATPS $\beta$ ) and increase in ATP synthesis is activated by leucine, which then improves insulin secretion disorder in human diabetic islets [10]. In one study, Genipin could increase ATP production in islets of diabetic mice by inhibiting UCP2, which improved insulin secretory dysfunction [11]. ATP is co-secreted with insulin from pancreatic $\beta$ cells; released ATP, in turn, acts as a signaling molecule that regulates $\beta$-cell function by activating the purine 2 (P2) receptor located on the plasma membranes of $\beta$ cells [8]. The $\mathrm{Ca}^{2+}$ signaling pathway has been identified as an important downstream pathway of the $\mathrm{P} 2$ receptor signaling pathway. Extracellular ATP has often been shown to increase the intracellular free $\mathrm{Ca}^{2+}$ concentration [12-14], which, in turn, not only promotes insulin secretion but also activates the calmodulin (CaM)-Protein kinase B (Akt) signaling pathway in various cell types including pancreatic $\beta$ cells $[15,16]$.

Family with sequence similarity 3 , member $A$ (FAM3A) is the first member of the FAM3 gene family. It is ubiquitously expressed in the tissues of humans and rodents [17]. We had previously demonstrated that FAM $3 A$ is a new mitochondrial protein that enhances the production and release of ATP. FAM3A overexpression inhibits hepatic gluconeogenesis and lipogenesis by activating the ATP$\mathrm{Ca}^{2+}$-Akt pathway [18], which protects against hepatic ischemia/ reperfusion injury [19] and neuronal oxidative stress [20]. FAM3A is also known to facilitate vascular smooth muscle cell proliferation [21] and adipocyte differentiation [22] by promoting ATP production and release. FAM3A-induced ATP release in vascular smooth muscle cells plays a crucial role in regulating vasoconstriction and blood pressure [23]. In our previous study, we also showed that insulin secretion is significantly impaired in pancreatic $\beta$ cell-specific knockout FAM3A mice. Mechanistically, FAM3A-induced ATP release activates the CaM-forkhead box protein A2 (FOXA2) pathway to directly induce the expression of pancreatic-duodenal homeobox 1 (PDX1), the key regulator of insulin gene expression, and $\beta$-cell growth and proliferation [24]. However, the role of intracellular ATP in FAM3A-induced PDX1 expression and insulin secretion remains unclear. Although we demonstrated earlier that FAM $3 A$ is vital in controlling PDX1 expression and insulin secretion in genetically modulated FAM3A-deficient mice, the effect of acute inhibition of FAM3A in pancreatic islets on PDX1 expression, insulin secretion, and glucose metabolism remain to be examined.

In the current study, we aimed to determine the effects of acute inhibition of FAM $3 A$ on islet functions in vivo and also probed the contribution of intracellular ATP to FAM3A-induced PDX1 expression and insulin secretion in pancreatic $\beta$ cells.

\section{Materials and Methods}

\section{Animals}

C57BL/6, FAM3A $A^{\text {flox/flox }}$ control mice (Con), and $\beta$ cell-specific FAM3A gene knockout (BKO) mice were used in the study. All mice were male and $8-10$ weeks old. Mice were housed with unrestricted access to food and water. All animal protocols complied with all relevant ethical regulations and were approved by the Institutional Animal Care and Use Committee, the Experimental Animal Center, Fuwai Hospital, National Center for Cardiovascular Diseases, China.

\section{Knockdown of FAM $3 A$ in the pancreas}

To knock down pancreatic FAM3A expression in mice, we mixed three sets of siFAM3A (synthesized by Invitrogen). Using hydrodynamic injections, $400 \mu \mathrm{g}$ of siFAM3A dissolved in $0.8 \mathrm{~mL}$ PBS was rapidly injected in the tail vein as described previously [25]. The sequences of the three sets of siFAM3A are provided in Supplemental Table 1.

\section{Oral glucose tolerance test (OGTT)}

After $12 \mathrm{~h}$ of fasting, mice were subjected to an OGTT. Blood samples were collected, and glucose levels were measured using a glucometer at indicated time points $(0,15,30,60,90$, and $120 \mathrm{~min})$ after glucose ingestion. The dose of $\mathrm{D}$-glucose administration was $2 \mathrm{~g} / \mathrm{kg}$ of body weight. For determination of insulin levels, blood samples were collected at $0,15,30$, and 60 min after glucose administration, and insulin levels were measured using a rat/mouse insulin ELISA kit.

\section{Isolation and culture of islets}

As described previously [24], mice were anesthetized, and the upper part of the common bile duct near the hepatic portal vein was isolated and ligated. The duodenum was pulled with forceps and perfused with $3-5 \mathrm{~mL}$ of collagenase $V$ [Sigma, $0.5 \mathrm{mg} / \mathrm{mL}$ in Hank's Balanced Salt Solution (HBSS)] in the lower part of the common bile duct using an injection syringe. The pancreas was then isolated, collected in a $15 \mathrm{~mL}$ centrifuge tube containing $5 \mathrm{~mL}$ $0.5 \mathrm{mg} / \mathrm{mL}$ collagenase $\mathrm{V}$, and digested for $10 \mathrm{~min}$ at $38^{\circ} \mathrm{C}$. Subsequently, about $5 \mathrm{~mL} 10 \%$ fetal bovine serum (FBS in HBSS) was added to the tube containing the digested pancreas, and the tube was then placed on ice to stop digestion. The mixture was then filtered and centrifuged ( $1500 \mathrm{rpm}, 2 \mathrm{~min}$ at $4{ }^{\circ} \mathrm{C}$ ); the process was repeated thrice. Then, the precipitate was resuspended in HBSS, and the islets were viewed under a stereoscopic microscope. The 
islets were cultured in $10 \%$ FBS Roswell Park Memorial Institute Medium (RPMI) 1640 for $24 \mathrm{~h}$ and later transferred to a low attachment 24-well plate for glucose-stimulated insulin secretion experiments or insulin and protein analysis.

\section{Immunohistochemical and immunofluorescent staining}

Pancreas tissues were fixed in $4 \%$ paraformaldehyde and paraffin sections $(5 \mu \mathrm{m})$ were prepared. For immunohistochemistry, sections were stained with anti-FAM3A (Sigma-Aldrich, SAB1102488), anti-insulin (Abcam, ab181547), and anti-PCNA (Cell Signaling Technology, 2586) primary antibodies. After antibody incubation overnight, diaminobenzidine staining was performed. For immunofluorescent staining, HIT-T15 cells were fixed, permeabilized, blocked, and incubated with anti-FOXO1 antibodies (Cell Signaling Technology, 2880) at $4{ }^{\circ} \mathrm{C}$ overnight. On the next day, cells were stained with goat anti-rabbit Alexa Fluor 594. After nuclear staining with DAPI, images were observed under a confocal laser scanning microscope, and images were acquired.

\section{Real-time PCR}

Total RNA was extracted from $30 \mathrm{mg}$ of liver tissues in TRIzol reagent (Invitrogen, USA) according to the manufacturer's instructions. RNA $(3-5 \mu \mathrm{g})$ was converted to cDNA using a cDNA synthesis kit (Thermo Scientific, USA). The target genes were quantified using SYBR Green PCR Master Mix (TOYOBO, Japan). $\beta$-actin was used as an endogenous control. The primer sequences are listed in

\section{Supplemental Table 2.}
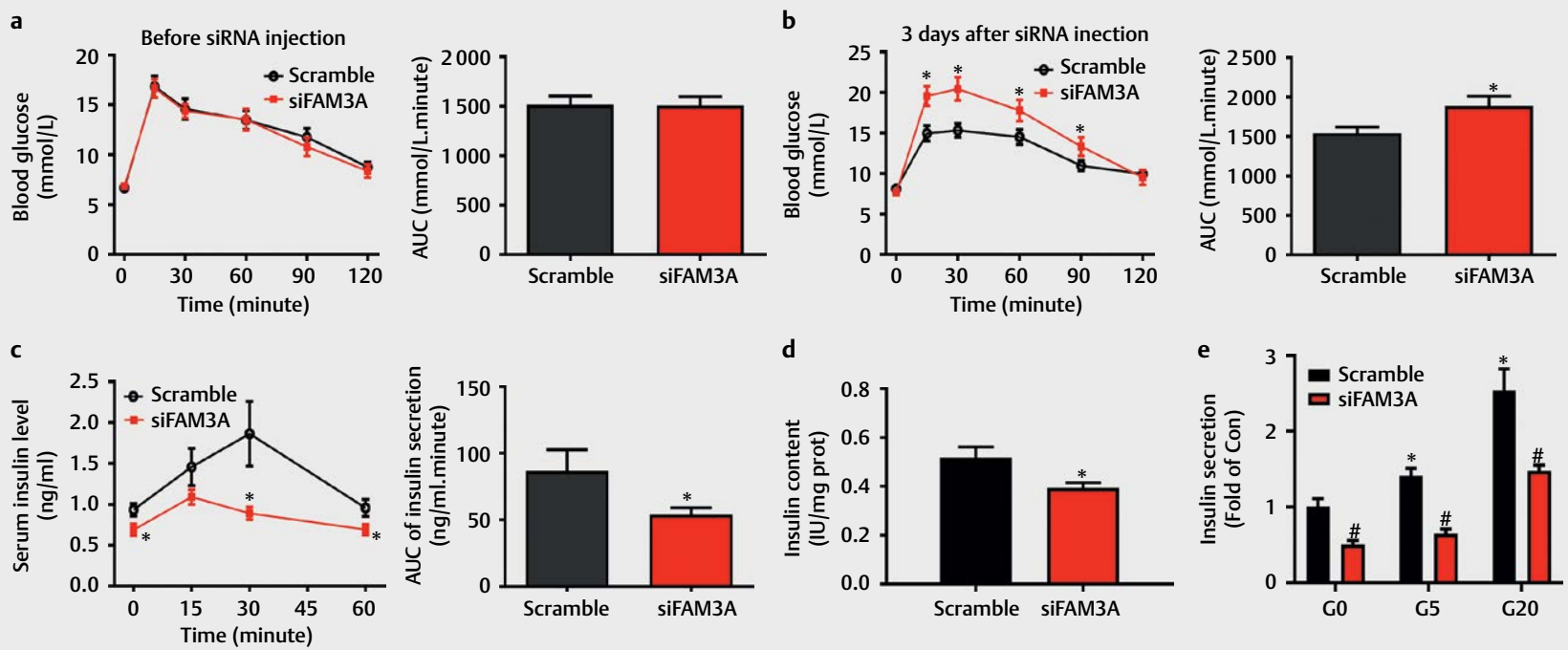

\section{Western blotting}

Cells or tissues were lysed in RIPA lysis buffer in the presence of proteinase inhibitors. Protein samples were separated by sodium dodecyl sulfate-polyacrylamide gel electrophoresis and transferred to nitrocellulose membrane. The membranes were then blocked in 5\% milk (in tris-buffered saline with Tween 20) for $1 \mathrm{~h}$ at room temperature and then incubated with primary antibodies [anti-FAM3A (Sigma-Aldrich, SAB1102488), anti-pAkt (Cell Signaling Technology, 9271), anti-Akt (Cell Signaling Technology, 9272), anti-pFOXO1 (Cell Signaling Technology, 9461), anti-FOXO1 (Cell Signaling Technology, 2880), anti-PDX1 (ABclonal, A3070), anti- $\beta$-actin (ZSGB Biotechnology, TA-09), and anti-GAPDH (Cell Signaling Technology, 5174)] overnight at $4{ }^{\circ} \mathrm{C}$. On the next day, the membranes were washed and incubated with secondary antibodies for $2 \mathrm{~h}$. Blots were visualized using enhanced chemiluminescence.

\section{Cell culture and treatment}

HIT-T15 cells and INS-1 cells were maintained in RPMI 1640 medium supplemented with $10 \%$ FBS. MIN6 cells were cultured in Dulbecco's Modified Eagle Medium (with high glucose) supplemented with $15 \%$ FBS. To inhibit the expression of the $\mathrm{P} 2$ receptors or $\mathrm{Ca}^{2+}$ signaling, the cells were incubated with $50 \mu \mathrm{M}$ pyridoxalphosphate-6-azophenyl-2',4'-disulfonic acid (PPADS), $50 \mu \mathrm{M}$ suramin, and $50 \mu \mathrm{M}$ Chlorpromazine (CPZ) or $10 \mu \mathrm{M}$ nifedipine for another $2 \mathrm{~h}$ after Ad-FAM3A infection for $24 \mathrm{~h}$. To detect insulin secretion, HIT-T15 cells were incubated in Krebs-Ringer bicarbonate (KRB; $115 \mathrm{mM} \mathrm{NaCl}, 24 \mathrm{mM}$ $\mathrm{NaHCO}_{3}, 5 \mathrm{mM} \mathrm{KCl}, 1 \mathrm{mM} \mathrm{MgCl}$, $2.5 \mathrm{mM} \mathrm{CaCl}_{2}, 25 \mathrm{mM}$ HEPES, $0.1 \%$ $\mathrm{BSA}, \mathrm{pH} 7.4$ ) in the absence of glucose for $1 \mathrm{~h}$ after infection with AdFAM3A for $24 \mathrm{~h}$. They were then incubated in KRB with different doses d

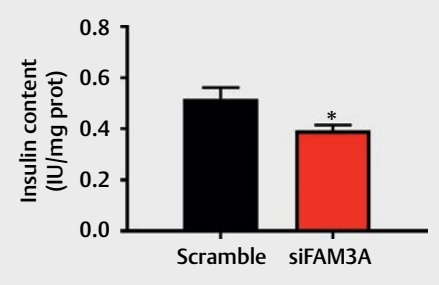

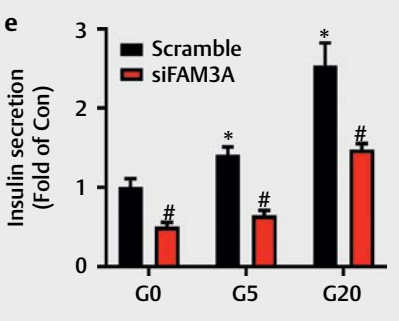

- Fig. 1 Acute FAM3A knockdown significantly impaired insulin secretion. Male C57BL/6 mice were injected with scramble or siFAM3A via tail vein hydrodynamic injection. (a) An oral glucose tolerance test (OGTT) was performed before siRNA injection. The area under the curve (AUC) of OGTT (day 0 ) is presented in the right panel. (b) OGTT on day 3 after tail injection of scramble or siFAM3A is shown. AUC of OGTT (day 3 ) is presented in the right panel. (c) Three days after siRNA injection, blood samples were collected from the tail vein at the first four time points $(0,15,30$, and $60 \mathrm{~min}$ ) of OGTT, and serum insulin levels were measured. The AUC of serum insulin is presented in the right panel. (d) Insulin content in islets of mice with acute FAM3A inhibition and the scramble group. (e) Glucose-stimulated insulin secretion in the scramble and siFAM3A groups. For (a-c), $\mathrm{N}=14-18$. For (d-e), $\mathrm{N}=6$. For (a-d), ${ }^{*} \mathrm{P}<0.05$ vs. scramble group. For (e), ${ }^{*} \mathrm{P}<0.05$ vs. scramble islets $(\mathrm{G} 0)$, \#P<0.05 between sifAM3A islets vs. corresponding scramble group under G0, G5, and G20 stimulation separately. G0: $0 \mathrm{mmol} / \mathrm{L}, \mathrm{G} 5: 5 \mathrm{mmol} / \mathrm{L}$, and G20: $20 \mathrm{mmol} / \mathrm{L}$ glucose. 


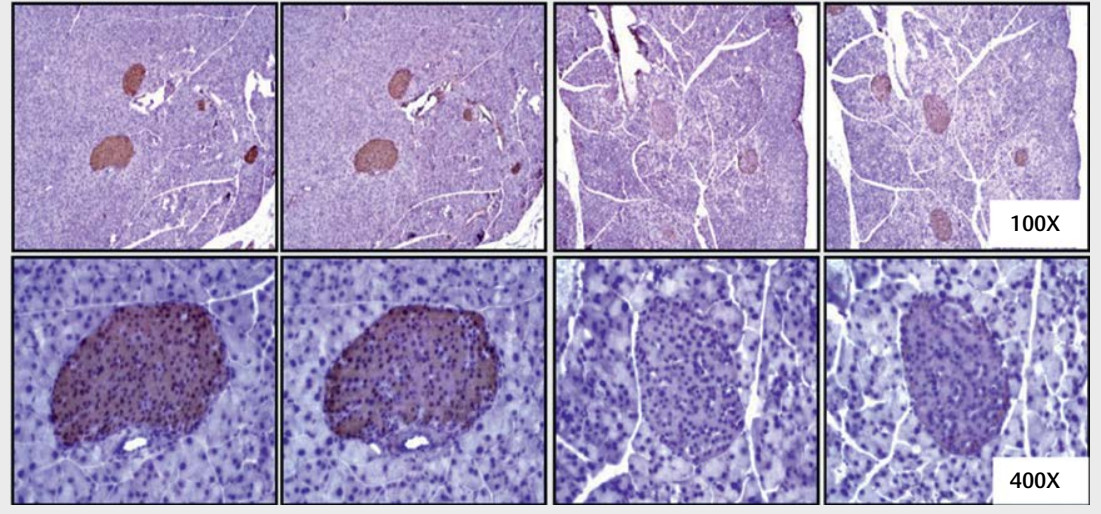

Scramble

SiFAM3A

b

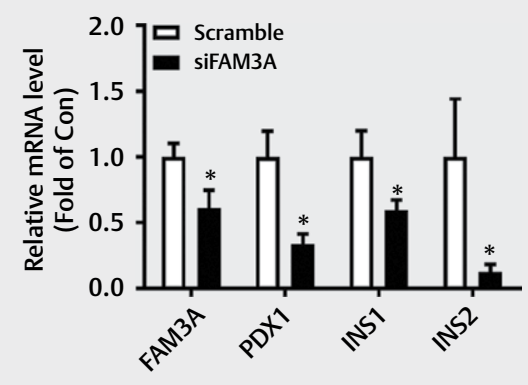

C
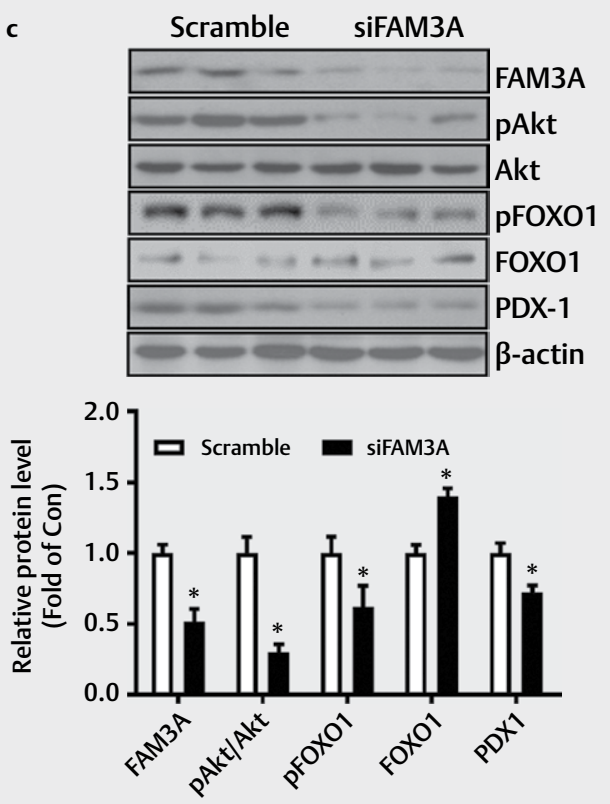

- Fig. 2 FAM3A knockdown reduced the expression of PDX1 in the pancreas. (a) FAM3A and insulin expressions in mouse pancreatic islets were measured by immunohistochemical analysis. (b) Changes in FAM3A, PDX1, INS1, and INS2 mRNA levels in the pancreas after siFAM3A injection. (c) FAM3A knockdown decreased pAkt and PDX1 protein expressions in the pancreas. The upper panel shows representative images and the lower panel shows statistics graphs. $\mathrm{N}=7-8 .{ }^{*} \mathrm{P}<0.05$ vs. scramble.

of glucose $(0,5 \mathrm{mM}, 20 \mathrm{mM})$ and $\mathrm{KCl}(30 \mathrm{mM})$. After $1 \mathrm{~h}$ of incubation, the supernatant was removed for insulin detection, and the insulin values were normalized by protein levels.

\section{Determination of ATP content}

To determine the ATP content, an ATP-Lite Assay Kit (Vigorous Biotechnology Beijing Co., Ltd) was used [18]. Cell culture media and cellular components were all collected. The ATP standard curve was prepared with standard ATP samples and a luminometer. The ATP content of the samples was determined using the ATP standard curve and normalized to their protein level.

\section{Determination of free cellular calcium levels}

HIT-T15 cells were infected with Ad-GFP or Ad-FAM3A for $24 \mathrm{~h}$. This was followed by incubation in KRB in the absence of glucose for
1 hour. HIT-T15 cells were incubated in KRB with different doses of glucose $(0,5 \mathrm{mM}, 20 \mathrm{mM})$ and $\mathrm{KCl}(30 \mathrm{mM})$. Then, $1 \mu \mathrm{M}$ of Fura-2 acetoxymethyl (AM) was added and was further incubated for $30 \mathrm{~min} . \mathrm{Ca}^{2+}$ levels were measured using an Olympus ix71 fluorescence microscope. For inhibition of the P2 receptors, L-type $\mathrm{Ca}^{2+}$ channels, or $\mathrm{Ca}^{2+}$ signaling, the cells were treated with $50 \mu \mathrm{M}$ PPADS, $50 \mu \mathrm{M}$ suramin, $50 \mu \mathrm{M} \mathrm{CPZ}$, or $10 \mu \mathrm{M}$ nifedipine for $1 \mathrm{~h}$ before Fura-2 AM treatment.

\section{Cell cycle analysis}

Cells were infected with different adenoviruses for $24 \mathrm{~h}$. For inhibition of the $\mathrm{P} 2$ receptors, cells were treated with $50 \mu \mathrm{M}$ suramin for another $2 \mathrm{~h}$, and then stained with propidium iodide using a $\mathrm{Cy}$ cleTEST PLUS DNA Reagent Kit (Becton Dickinson, USA). Cell cycles were measured with flow cytometry. 

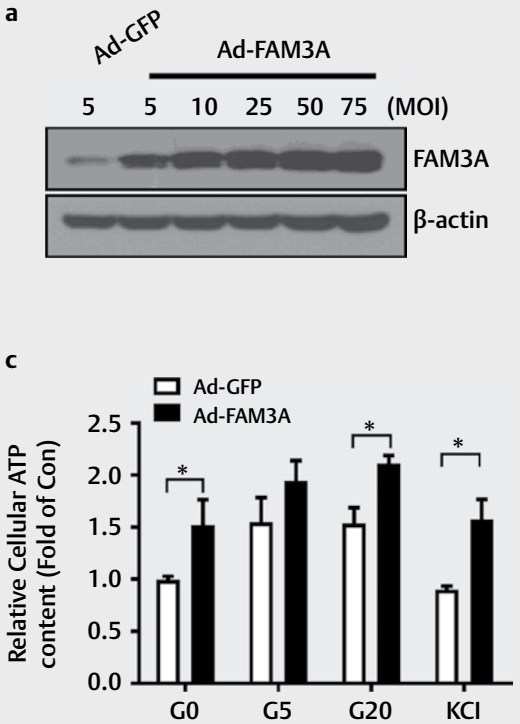

e

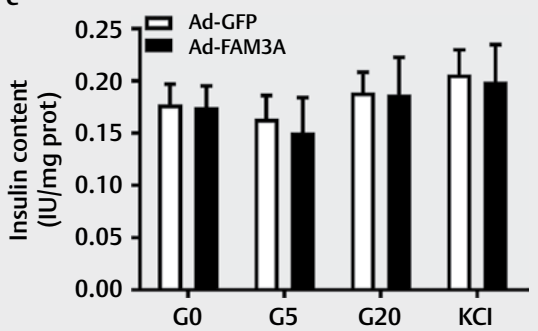

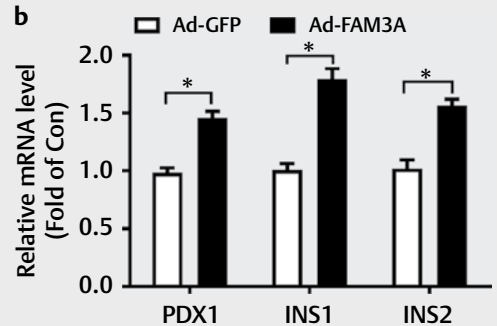

d

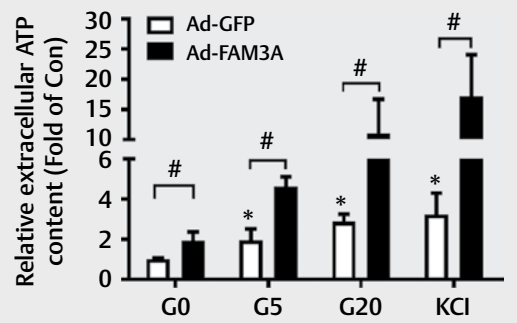

f

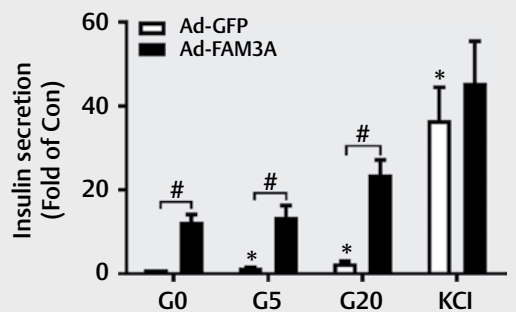

Fig. 3 Overexpression of FAM3A promoted ATP synthesis and insulin secretion in pancreatic $\beta$ cells. (a) A western blot assay showing Ad-FAM3A infection efficacy in HIT-T15 cells. (b) mRNA levels of PDX1, INS-1, and INS-2 in Ad-GFP, and Ad-FAM3A in HIT-T15 cells. * P $<0.05$ vs. indicated control. (c) FAM3A overexpression increased intracellular ATP levels in HIT-T15 cells. ${ }^{*} \mathrm{P}<0.05$ vs. indicated control. (d) The effect of FAM3A overexpression on extracellular ATP content in HIT-T15 cells. ${ }^{*} \mathrm{P}<0.05$ vs. Ad-GFP (G0); $\# \mathrm{P}<0.05$ vs. indicated controls. Effect of FAM3A overexpression on (e) insulin content and (f) insulin secretion in HIT-T15 cells. *P<0.05 vs. Ad-GFP (G0); \#P<0.05 vs. indicated control. G0: $0 \mathrm{mmol} / \mathrm{L}, \mathrm{G}$ : $5 \mathrm{mmol} / \mathrm{L}$, and G20: $20 \mathrm{mmol} / \mathrm{L}$ glucose. $\mathrm{N}=5-7$.

\section{3-(4,5-dimethylthiazol-2-yl)-2,5-diphenyl tetrazolium bromide (MTT) assay}

Cells were seeded into 96-well plates and infected with different adenoviruses for $24 \mathrm{~h}$. For inhibition of the $\mathrm{P} 2$ receptors, cells were treated with $50 \mu \mathrm{M}$ suramin for another $2 \mathrm{~h}$. Then, $0.5 \mathrm{mg} / \mathrm{mL}$ of MTT was added to each well. After $4 \mathrm{~h}$ of incubation at $37^{\circ} \mathrm{C}$, the supernatant was discarded, and the precipitate was dissolved with dimethyl sulfoxide for $15 \mathrm{~min}$. Absorbance was measured at $490 \mathrm{~nm}$ and normalized to the control values.

\section{Statistical analysis}

Data are presented as the mean \pm standard error of the mean. The normal distribution of data was determined with a Shapiro-Wilk test. Statistical significance of differences between the groups was analyzed with a $t$-test or Mann-Whitney test (two groups) or with a oneway ANOVA/Kruskal-Wallis test, followed by Bonferroni's or Dunn's post-hoc analysis, respectively (multiple groups). P-values $<0.05$ were considered statistically significant.

\section{Results}

\section{Acute FAM 3 A knockdown significantly impairs insulin secretion}

To evaluate the effect of acute FAM3A knockdown in pancreatic islets on insulin secretion, FAM3A expression in mouse pancreatic islets was transiently inhibited by hydrodynamic siRNA transfection in vivo. Before injecting siRNA, mice were randomly categorized into two groups. No significant difference was noted in terms of glucose tolerance between the two groups ( $>$ Fig. 1a). On day 3 post siFA$\mathrm{M} 3 \mathrm{~A}$ transfection, although the fasting glucose level in the two groups of mice did not exhibit significant difference, siFAM3A-treated mice exhibited significant glucose intolerance when compared to the scramble-treated mice ( $>$ Fig. 1b). Acute pancreatic FAM3A knockdown significantly decreased fasting serum insulin levels and weakened insulin secretion after a glucose load ( $>$ Fig. 1c). We then examined the islets of acute FAM3A inhibited mice and observed decreased insulin content and impaired glucose-stimulated insulin secretion compared to those in the scramble group ( $\triangleright$ Figs. 1d-e). These findings suggest that acute inhibition of pancreatic FAM3A significantly impaired insulin secretion. 

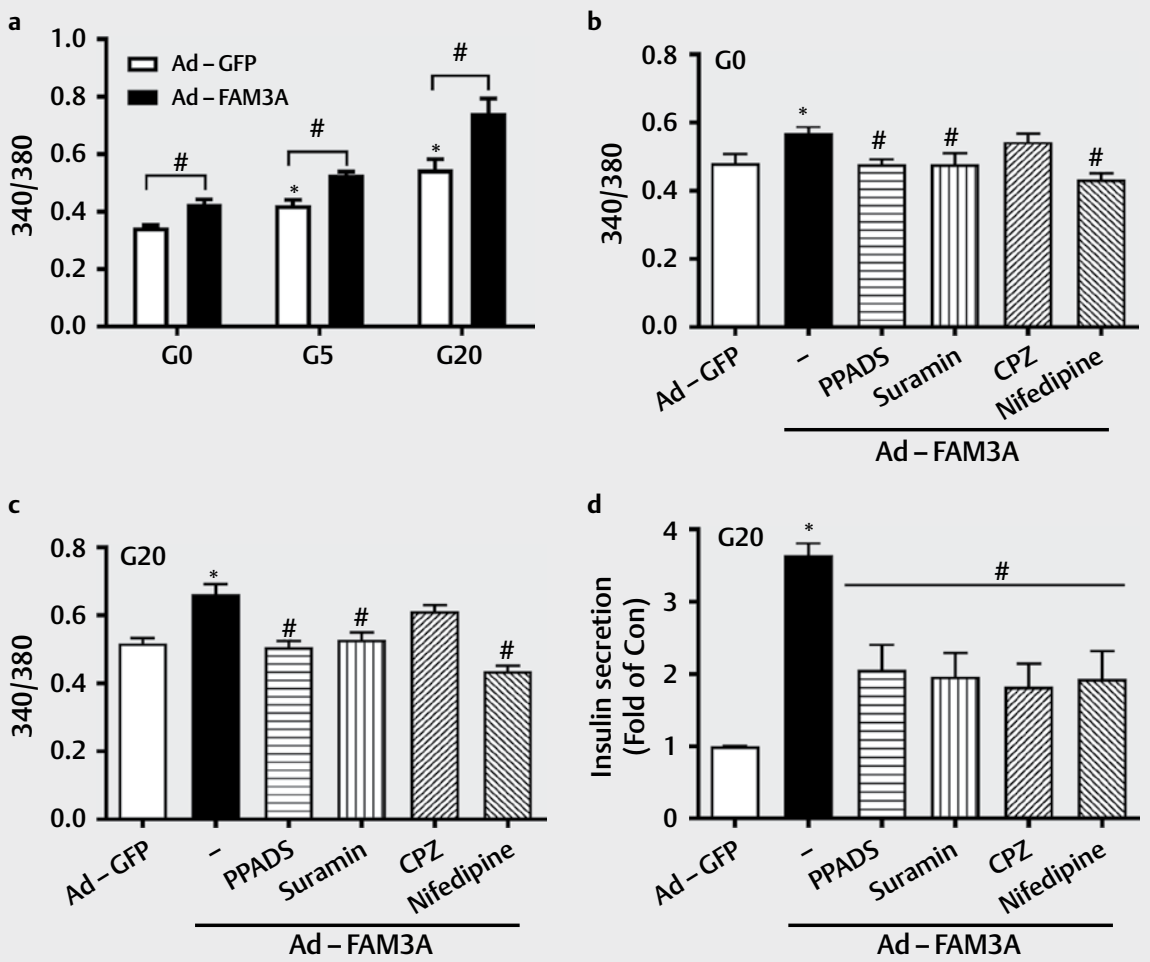

\begin{abstract}
- Fig. 4 Intracellular ATP contributed to FAM3A-induced increase in $\mathrm{Ca}^{2+}$ level and insulin secretion in HIT-T15 cells. (a) Effect of FAM3A overexpression of cellular calcium levels under different stimulants (G0, G5, and G20). ${ }^{*} \mathrm{P}<0.05$ vs. Ad-GFP (G0); \#P<0.05 vs. indicated control. (b-c) The effect of $\mathrm{P} 2$ receptor inhibitors (PPADS and suramin), CaM inhibitor (CPZ), and L-type calcium channels inhibitor (nifedipine) on FAM3A-induced cellular calcium elevation in different concentrations of glucose (G0 and G20) in HIT-T15 cells. ${ }^{*} \mathrm{P}<0.05$ vs. Ad-GFP; \#P<0.05 vs. Ad-FAM3A. (d) The effect of PPADS, suramin, CPZ, and nifedipine on FAM3A-promoted insulin secretion in HIT-T15 cells. ${ }^{*} \mathrm{P}<0.05$ vs. Ad-GFP; \#P<0.05 vs. Ad-FAM3A. G0: $0 \mathrm{mmol} / \mathrm{L}, \mathrm{G} 5: 5 \mathrm{mmol} / \mathrm{L}$, and G20: $20 \mathrm{mmol} / \mathrm{L}$ glucose. $\mathrm{N}=5$.
\end{abstract}

\section{FAM3A knockdown reduced PDX1 expression in the pancreas}

Immunohistochemical staining, real-time PCR, and immunoblotting assays revealed significantly lower expression of FAM3A in pancreatic islets of siFAM3A-treated mice than that in the control mice ( $\vee$ Figs. $2 \mathbf{2 a}-\mathbf{c}$ ). This repression of FAM3A expression led to significantly reduced insulin expression in the pancreases of siFAM3Atreated mice compared to that in the control mice ( $\triangleright$ Figs. 2a-b). Importantly, acute FAM3A repression caused a decrease in PDX1 mRNA and protein expressions in the pancreases of the mice ( Figs. 2b-c). The Akt-FOXO1 pathway plays a vital role in regulating $\beta$-cell functions [26-28], therefore, we further evaluated whether acute FAM3A repression also influenced the Akt-FOXO1 pathway. A western blot assay indicated acute FAM3A knockdown in the pancreas significantly repressed Akt phosphorylation and FOXO1 phosphorylation and increased non-phosphorylated FOXO1 levels ( $\triangleright$ Fig. 2c). Thus, acute FAM3A inhibition reduced PDX1 and insulin gene expressions in the pancreas of the mice.

\section{FAM 3 A overexpression promoted ATP synthesis and insulin secretion in pancreatic $\beta$ cells}

Considering that FAM $3 \mathrm{~A}$ is a mitochondrial protein that increases ATP production in various cell lines, we evaluated the effects of FAM $3 A$ on ATP synthesis and insulin secretion in pancreatic $\beta$ cells. First, we examined the efficacy of FAM $3 A$ adenovirus overexpres- sion in HIT-T15 cells $24 \mathrm{~h}$ post-infection through a western blot assay ( $\vee$ Fig. 3a); for this experiment, we chose viruses with an $\mathrm{MOI}$ of 25. FAM3A overexpression upregulated mRNA levels of PDX1, INS1, and INS2 genes ( $>$ Fig. $3 \mathbf{b}$ ) in HIT-T15 cells and also led to increased cellular ATP content with the presence of different concentrations of glucose ( $0 \mathrm{mmol} / \mathrm{L}$ glucose, $\mathrm{G} 0 ; 20 \mathrm{mmol} / \mathrm{L}, \mathrm{G} 20)$, and $\mathrm{KCl}$ compared to those in control cells ( $\nabla \mathbf{F i g} . \mathbf{3 c}$ ). Overexpression of FAM3A also augmented ATP release with or without a glucose challenge in HIT-T15 cells. ( $>$ Fig. 3d) and significantly promoted insulin secretion with or without glucose stimulation, but had little effect on insulin content in HIT-T15 cells ( $\triangleright$ Figs. 3e-f). The unchanged insulin content after FAM3A overexpression is likely due to a higher secretion rate than that in control cells. These findings suggest that FAM3A overexpression promoted ATP synthesis and insulin secretion with or without glucose stimulation in HIT-T15 cells.

Intracellular ATP contributed to FAM3A-induced increase in $\mathrm{Ca}^{2+}$ levels and insulin secretion in HIT-T15 cells

To evaluate the roles of intracellular and extracellular ATP on FA$\mathrm{M} 3 \mathrm{~A}$-induced $\mathrm{Ca}^{2+}$ levels and insulin secretion, the roles of nifedipine and $\mathrm{P} 2$ receptor inhibitors were evaluated in HIT-T15 cells. We found elevated $\mathrm{Ca}^{2+}$ levels in HIT-T15 cells treated with glucose at $5 \mathrm{mmol} / \mathrm{L}$ and $20 \mathrm{mmol} / \mathrm{L}$ when compared to $0 \mathrm{mmol} / \mathrm{L}$ ( $>$ Fig. $4 a$ ). FAM3A overexpression caused an increase in intracellular free $\mathrm{Ca}^{2+}$ 
a
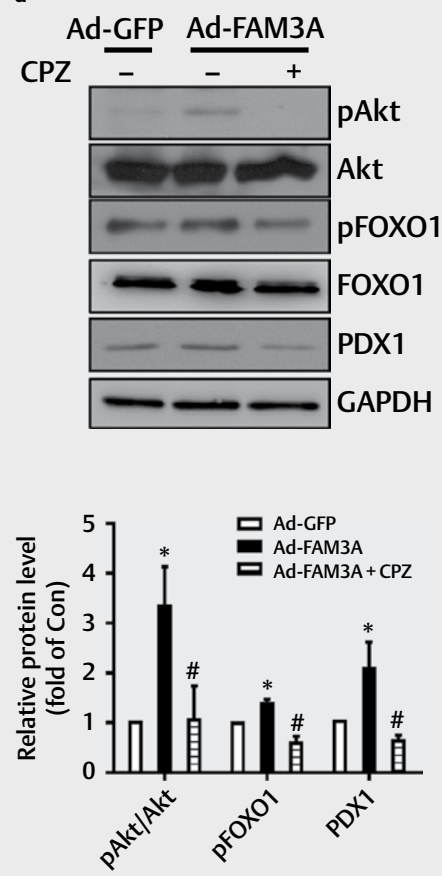

b

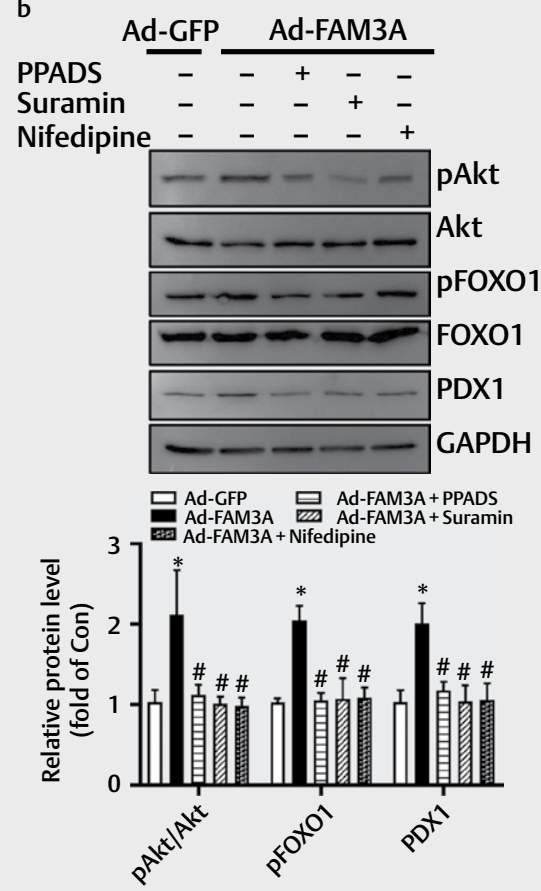

- Fig. 5 Intracellular ATP contributed to FAM3A-induced Akt activation and PDX1 upregulation. (a) The effect of CaM inhibitor (CPZ) on FAM3Ainduced Akt-FOXO1 activation and PDX1 upregulation in HIT-T15 cells. The upper panel shows a representative image, and the lower panel shows a statistical graph. (b) Extended exposure to PPADS, suramin, and nifedipine for 24h weakened FAM3A-induced Akt-FOXO1 phosphorylation and PDX1 upregulation. The upper panel shows a representative image and the lower panel shows a statistical graph. $N=4-5,{ }^{*} \mathrm{P}<0.05$ vs. Ad-GFP, \#P<0.05 vs. Ad-FAM3A.

levels with or without glucose stimulation ( $\mathbf{F i g . 4 a ) . ~ I m p o r t a n t l y , ~}$ inhibition of P2 receptors using PPADS or suramin, and L-type $\mathrm{Ca}^{2+}$ channels using nifedipine, weakened FAM3A-induced increase in intracellular $\mathrm{Ca}^{2+}$ levels in HIT-T15 cells at both $0 \mathrm{mmol} / \mathrm{L}$ and $20 \mathrm{mmol} / \mathrm{L}$ glucose concentration ( $\triangleright$ Figs. 4b-c). In contrast, inhibition of CaM using CPZ failed to affect FAM3A-promoted elevation of cellular $\mathrm{Ca}^{2+}$ levels in the presence of $0 \mathrm{mmol} / \mathrm{L}$ and $20 \mathrm{mmol} / \mathrm{L}$ glucose in HIT-T15 cells ( $\triangleright$ Figs. 4b-c). However, inhibition of P2 receptors, CaM, and L-type $\mathrm{Ca}^{2+}$ channels all impaired FAM3A-promoted insulin secretion in HIT-T15 cells in the presence of $20 \mathrm{mmol} / \mathrm{L}$ glucose ( $\triangleright$ Fig. 4d). Overall, these findings suggest that both intracellular and extracellular ATP contribute to FAM3A-induced increase in $\mathrm{Ca}^{2+}$ levels and insulin secretion.

\section{Intracellular ATP contributed to FAM3A-induced Akt activation and PDX1 upregulation}

Activation of Akt and PDX1 is critical for maintaining pancreatic $\beta$-cell mass and function [29-31]. In vivo, FAM3A knockdown markedly repressed the Akt-FOXO1 pathway and PDX1 expression, therefore, we further evaluated the effects of both intracellular and extracellular ATP on FAM3A-induced Akt activation in cultured cells. In HIT-T15 cells, FAM3A overexpression significantly promoted Akt and FOXO1 phosphorylation, increased FOXO1 levels, and upregulated PDX1 protein levels, but this effect was reversed by the CaM inhibitor CPZ ( Fig. 5a). Moreover, inhibitors of $\mathrm{P} 2$ receptors (PPADS and suramin) and the L-type $\mathrm{Ca}^{2+}$ channels (nifedipine) could repress FAM3A-induced elevations of pAkt, pFOXO1, and
PDX1 protein levels ( $>$ Figs. 5a-b). Collectively, intracellular ATP also contributed to FAM3A-induced Akt activation and PDX1 upregulation, likely by closing the ATP-sensitive potassium channels to open the L-type $\mathrm{Ca}^{2+}$ channels.

FOXO1 can inhibit PDX1 expression by interfering with the binding of FOXA2 to the promoter region of the PDX1 gene [32], therefore, the role of FOXO1 inactivation in FAM3A-induced PDX1 upregulation was evaluated. Consistent with phosphorylation, FAM3A overexpression reduced the nuclear distribution of FOXO1, which was inhibited by an inhibitor of $\mathrm{P} 2$ receptors (suramin) and CaM inhibitor (CPZ) in HIT-T15 cells (> Fig. 6a). However, FOXO1 overexpression was determined to have no significant effect on PDX1 protein expression in three independent pancreatic $\beta$-cell lines (HITT15 cells, INS-1 cells, and MIN6 cells; Figs. $\mathbf{6 b - d )}$ ). Thus, as per these findings, Akt-mediated FOXO1 inactivation is not likely involved in FAM3A-induced PDX1 activation in pancreatic $\beta$ cells.

\section{Intracellular ATP contributed to FAM3A-induced proliferation of pancreatic $\beta$ cells}

The proliferation of various cell types is stimulated by Akt [19, 21, 22]; likewise, the contributions of both intracellular and extracellular ATP in FAM $3 A$-induced proliferation of pancreatic $\beta$ cells were further evaluated. In HIT-T15 cells, FAM3A overexpression elevated the proportion of S phase (DNA synthesis phase) cells and decreased G1/G2 phase cells as determined by cell cycle analysis ( $\vee$ Fig. 7a). Besides, the MTT assay also indicated stimulation of the proliferation of $\beta$ cells by FAM $3 A$ overexpression ( $\vee$ Fig. 7b). In MIN6 cells, FAM3A overexpression also 
a

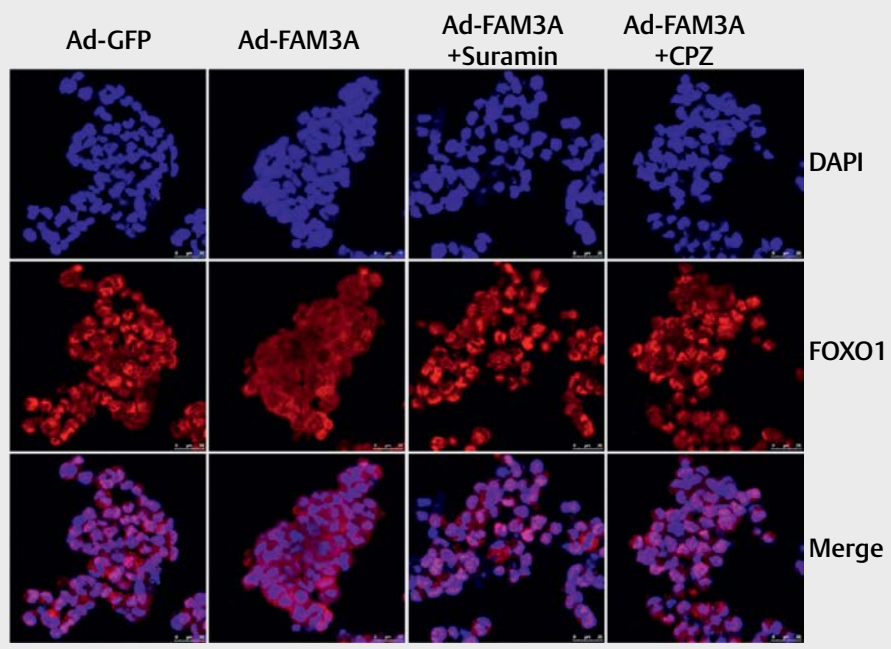

b

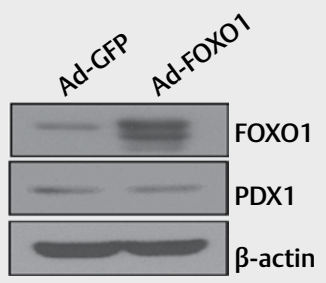

HIT-T15 cells

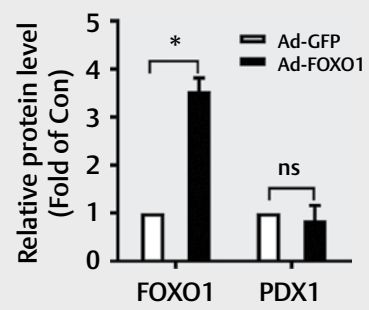

c

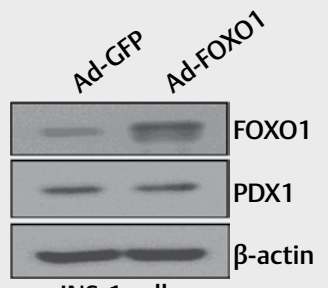

INS-1 cells

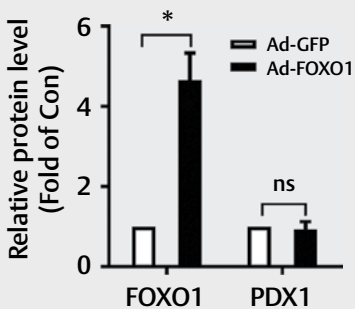

d

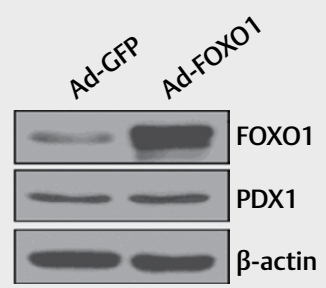

MIN6 cells

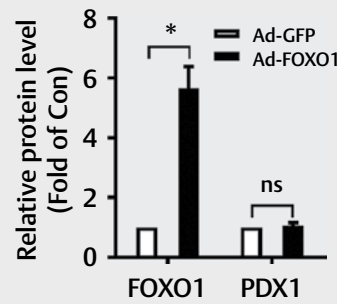

- Fig. 6 Akt-mediated FOXO1 inactivation is not involved in FAM3A-induced PDX1 upregulation. (a) Representative immunofluorescent staining for FOXO1 with different treatments. Nuclei stained with DAPI are in blue. (b-d) Western blot assay to analyze FOXO1 and PDX1 protein levels after Ad-FOXO1 infection in (b) HIT-T15 cells, (c) INS-1 cells, and (d) MIN6 cells. The upper panel shows representative images and the lower panel shows statistical graphs. $\mathrm{N}=3-4,{ }^{*} \mathrm{P}<0.05$ vs. Ad-GFP. ns: no significant difference.

increased the percentage of $S$ phase cells but decreased that of $\mathrm{G} 1 / \mathrm{G} 2$ phase cells, which was inhibited by suramin ( $\vee$ Figs. 7c-d). The results of MTT assay also revealed that FAM3A overexpression stimulated MIN6 cell proliferation, but was inhibited by a P2 receptor inhibitor (suramin) and L-type $\mathrm{Ca}^{2+}$ channels inhibitor (nifedipine; - Fig. 7e). Immunohistochemical staining showed inhibition of $\beta$-cell proliferation in both acute FAM3A knockdown and BKO mice ( $>$ Figs. 7f-g). Overall, both intracellular and extracellular ATP contributed to the FAM3A-induced proliferation of pancreatic $\beta$ cells.

\section{Discussion}

In this current study, we have provided new evidence that acute FAM3A inhibition in the pancreas impaired insulin synthesis and secretion. Although gene knockout animals are powerful models for exploring gene functions, they always lead to genetic compensation [33-35]. Moreover, inhibition, but not knockout, can mimic the effects of target gene repression in the progression of diseas- es. RNAi has been widely used in gene function analysis and gene therapy [36]. Acute FAM3A knockdown in the pancreas significantly repressed insulin expression and secretion and caused glucose intolerance in mice, further supporting our previous findings using $\beta$ cell-specific FAM3A gene knockout mice [24]. We found that the responsiveness and ability to secrete insulin of isolated islets toward different doses of glucose in the siFAM3A group were damaged. Overall, both genetic deficiency and pathophysiological repression of FAM $3 A$ in pancreatic islets were found to affect cellular insulin content and secretion.

We showed that intracellular ATP also contributed to FAM3Ainduced PDX1 expression and insulin secretion. FAM3A-promoted elevation of cellular ATP also increased cellular $\mathrm{Ca}^{2+}$ levels likely by closing ATP-sensitive potassium channels and opening L-type $\mathrm{Ca}^{2+}$ channels. Intracellular ATP elevation can trigger the opening of $\mathrm{L}$-type $\mathrm{Ca}^{2+}$ channels to increase cellular $\mathrm{Ca}^{2+}$ concentrations, while extracellular ATP can be secreted as a signaling molecule to produce a variety of biological effects $[37,38]$. The $\mathrm{P} 2$ receptor is the 
a

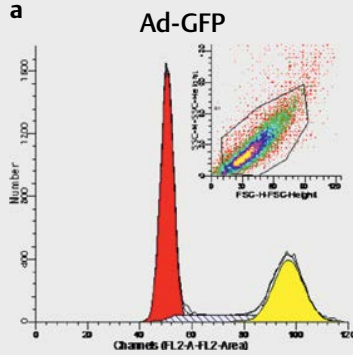

C

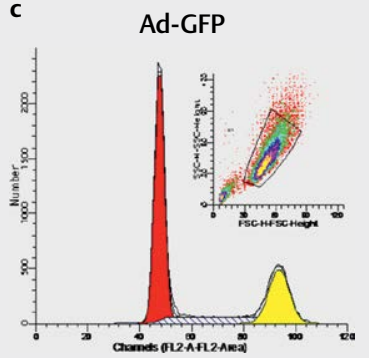

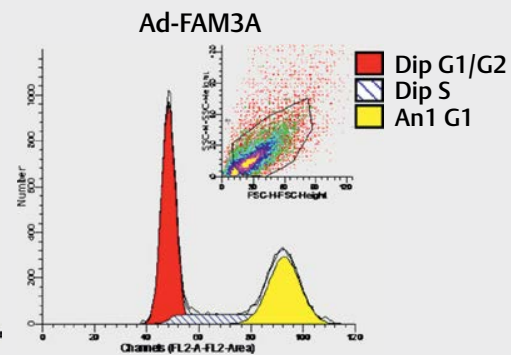
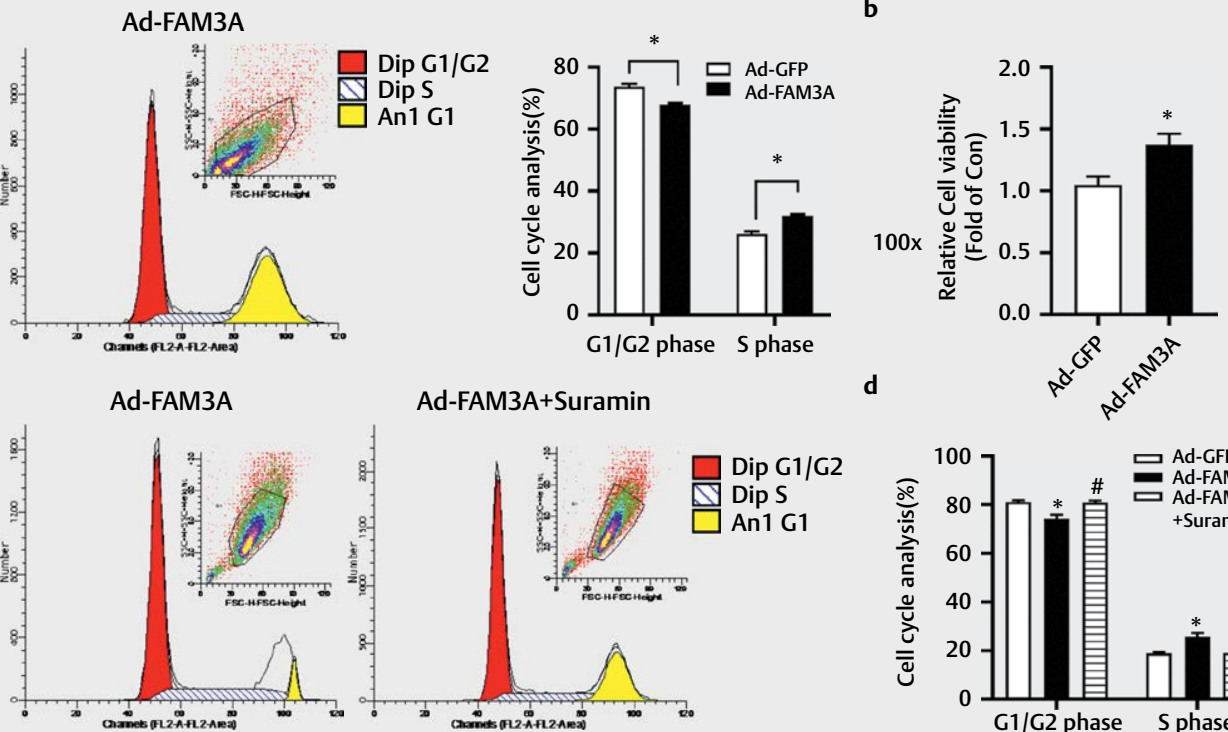

Ad-FAM3A+Suramin
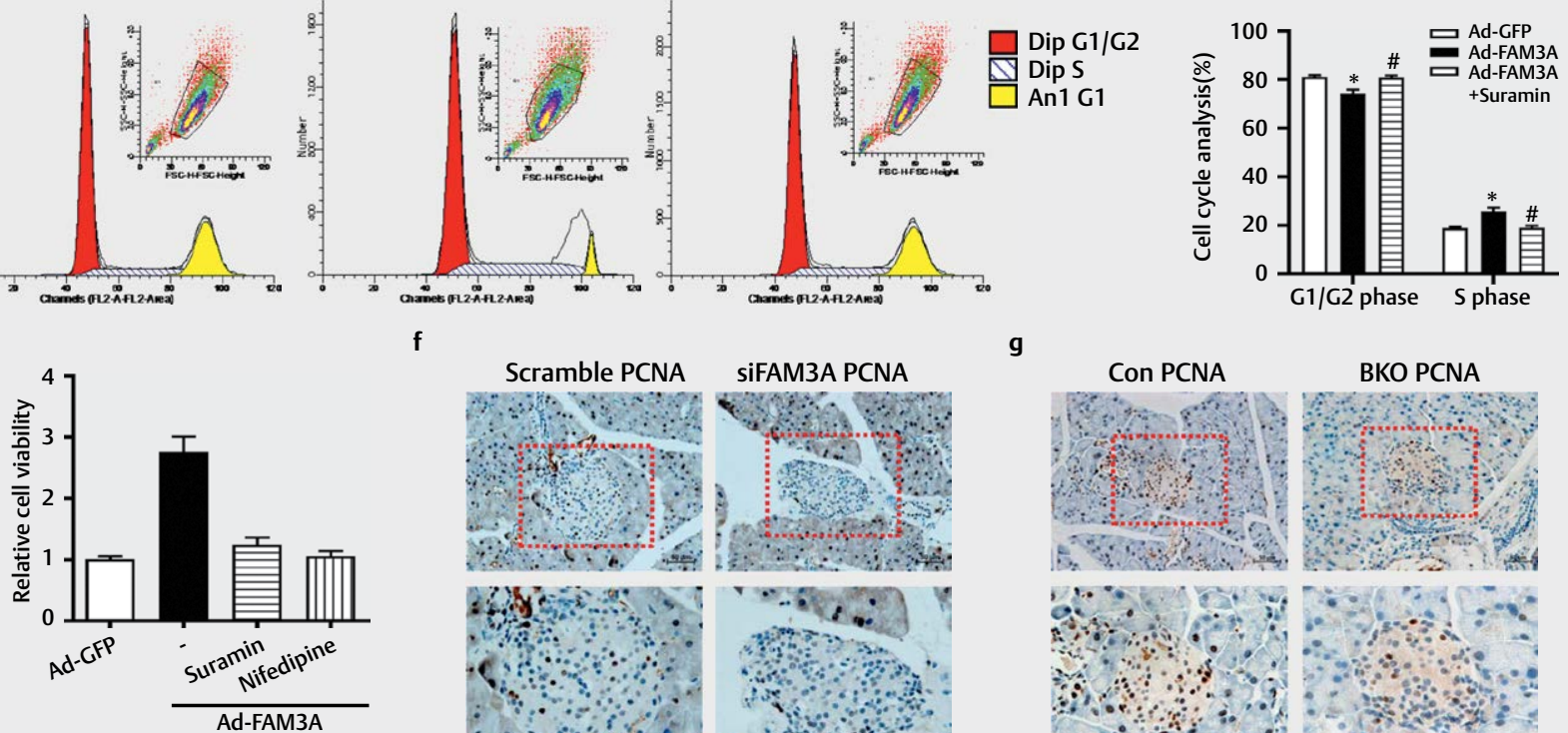

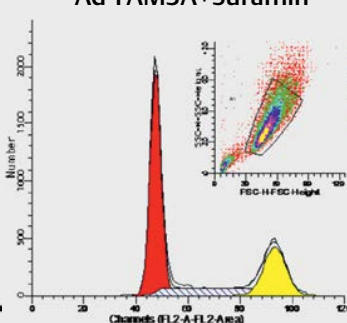

g
Dip G1/G2

Dip S

An1 G1
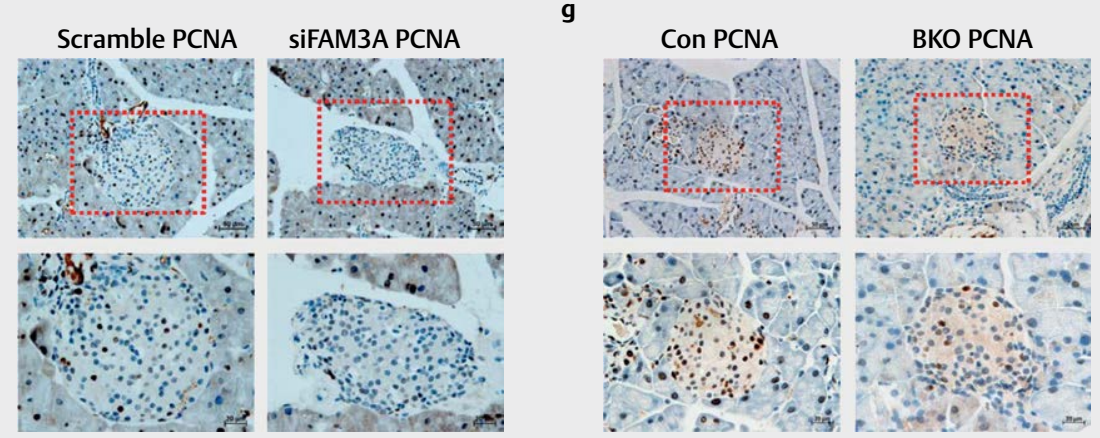

Fig. 7 Intracellular ATP contributed to FAM3A-induced proliferation of pancreatic $\beta$ cells. (a) The cell cycle analysis was performed after Ad-FAM3A infection in HIT-T15 cells. The left panel shows a representative image and the right panel shows a statistical graph. (b) MTT assay to analyze the effect of FAM3A overexpression on cell viability in HIT-T15 cells. In a MIN6 cell line, analysis of cell cycle showed the effect of suramin on FAM3Ainduced cell proliferation. (c) Representative images of the cell cycle, (d) statistical graphs of panel (c). (e) Cells exposed to suramin and nifedipine for $24 \mathrm{~h}$ weakened the effect of FAM3A on cell viability. Immunohistochemical staining of PCNA in (f) acute FAM3A knockdown mice and ( $\mathbf{g}$ ) $\beta$ cell-specific FAM3A gene knockout (BKO) mice. $N=4-5,{ }^{*} \mathrm{P}<0.05$ vs. Ad-GFP, $\# \mathrm{P}<0.05$ vs. Ad-FAM3A.

receptor of exogenous ATP and is of two types, P2X and P2Y receptors. $\mathrm{P} 2 \mathrm{X}$ receptor subtypes are ligand-gated ion channel type receptors that allow $\mathrm{Ca}^{2+}$ to pass through. A P2Y receptor isoform is a $G$ protein-coupled receptor, which can increase the level of IP3 and cause the release of $\mathrm{Ca}^{2+}$ from the endoplasmic reticulum $[38,39]$. Glucagon-like peptide- 1 has been shown to promote insulin secretion through augmentation of ATP production and increase in $\mathrm{Ca}^{2+}$ levels [40]. In this study, we found that inhibitors of $\mathrm{P} 2$ receptors (PPADS and suramin), and the L-type $\mathrm{Ca}^{2+}$ channels (nifedipine) weakened FAM3A-induced elevation of cellular $\mathrm{Ca}^{2+}$ levels and insulin secretion. These results, along with the previous findings, suggest that both intracellular and extracellular ATP contribute to FAM3A-induced increase in cellular $\mathrm{Ca}^{2+}$ levels, PDX1 upregulation, and insulin secretion.

Overexpression of FAM3A not only elevated the mRNA levels of insulin genes but also increased intracellular ATP and $\mathrm{Ca}^{2+}$ levels. These results indicate that FAM 3 A could promote both insulin synthesis and secretion. Consistent with our previous findings in MIN6 cells [24], we did not observe any increase in the intracellular insu- lin content. This might be because most of the additional synthetic insulin being released from the cells is promoted by ATP and $\mathrm{Ca}^{2+}$ elevation. A study in rat islets also showed that one week of leucine treatment also promoted glucose-induced insulin secretion, but reduced the cellular insulin content [41].

FAM3A induces Akt activation in various cell types to alleviate diabetes and fatty liver, protect against neuronal oxidative stress, and promote vascular smooth muscle cell proliferation [18, 20, 21]. FOXO1 is a direct downstream target gene of Akt. The Akt-FOXO1 pathway mediates the protection of FAM3A in hepatic ischemia/ reperfusion injury [19] and promotes osteoprotegerin-induced $\beta$-cell proliferation by [42]. Liraglutide protects against apoptosis and facilitates the survival of pancreatic $\beta$ cells in an Akt-dependent manner [26]. Akt-FOXO1 was also found to mediate quercetin's effect on restoring $\beta$-cell mass and functions [28]. PDX1 is also a key regulator of $\beta$-cell proliferation and differentiation. Loss of PDX1 led to mouse pancreatic agenesis [43], while PDX1 deficiency in acinar was found to cause cell senescence [44]. Our results also 
showed that acute FAM3A repression and $\beta$ cell-specific FAM3A gene knockout could impair pancreatic $\beta$-cell proliferation.

FOXO1 can interfere with the binding of FOXA2 to the promoter region of the PDX1 gene [32]. Although we found that FAM3A inactivated FOXO1, overexpression of FOXO1 failed to inhibit PDX1 in various pancreatic $\beta$-cell lines. This suggests that the inactivation of FOXO1 does not possibly have a role in FAM3A-induced PDX1 and insulin expressions in pancreatic $\beta$ cells.

In summary, our current and previous findings reveal that both intracellular and extracellular ATP contributed to FAM3A-induced increase in cellular $\mathrm{Ca}^{2+}$ levels, PDX1 expression, and insulin secretion. Moreover, FAM3A potentially influences the proliferation of pancreatic $\beta$ cells. Thus, FAM $3 A$ is a potential target for the treatment of islet dysfunction and diabetes.

\section{Author Contributions}

H.Y. performed experiments and contributed to the data collection and discussion. Z.C. drafted the original manuscript and provided technical assistance. H.Z., W.Y., J.Y., and X.L. contributed to the data analysis. Y.M. and R.X. were involved in solving methodology issues and animal preparation. Z.W. revised the manuscript. Y.C. and J.Y. designed the experiments and assisted in funding acquisition and checking the data authenticity. All authors have read and approved the manuscript.

\section{Funding}

This research was funded by Beijing Natural Science Foundation (7212123/7171006/7204320), the National Natural Science Foundation of China (82070844/81670787/81670748/81471035/818 $70551 / 81800367 / 81900492)$, the National Key Research Program of China (2016YFC0903000/2017YFC0909600) and the State Key Laboratory of Cardiovascular Disease Grant (2018fk-02).

\section{Conflict of Interest}

The authors declare that they have no conflict of interest.

\section{References}

[1] Guariguata L, Whiting DR, Hambleton I et al. Global estimates of diabetes prevalence for 2013 and projections for 2035. Diabetes Res Clin Pract 2014; 103: 137-149. doi:10.1016/j.diabres.2013.11.002

[2] Gerber PA, Rutter GA. The role of oxidative stress and hypoxia in pancreatic beta-cell dysfunction in diabetes mellitus. Antioxid Redox Signal 2017; 26: 501-518. doi:10.1089/ars.2016.6755

[3] Berchtold LA, Prause M, Størling J et al. Cytokines and pancreatic $\beta$-cell apoptosis. Adv Clin Chem 2016; 75: 99-158. doi:10.1016/bs. acc.2016.02.001

[4] Marasco MR, Linnemann AK. $\beta$-cell autophagy in diabetes pathogenesis. Endocrinology 2018; 159: 2127-2141. doi:10.1210/en.2017-03273

[5] Helman A, Avrahami D, Klochendler A et al. Effects of ageing and senescence on pancreatic $\beta$-cell function. Diabetes Obes Metab 2016; 18 Suppl 1: 58-62. doi:10.1111/dom.12719
[6] Gerencser AA. Metabolic activation-driven mitochondrial hyperpolarization predicts insulin secretion in human pancreatic beta-cells. Biochim Biophys Acta Bioenerg 2018; 1859: 817-828. doi:10.1016/j. bbabio.2018.06.006

[7] Zhang CY, Baffy G, Perret P et al. Uncoupling protein-2 negatively regulates insulin secretion and is a major link between obesity, $\beta$ cell dysfunction, and type 2 diabetes. Cell 2001; 105: 745-755. doi:10.1016/s0092-8674(01)00378-6

[8] Wang C, Geng B, Cui Q et al. Intracellular and extracellular adenosine triphosphate in regulation of insulin secretion from pancreatic $\beta$ cells ( $\beta$ ). J Diabetes 2014; 6: 113-119. doi:10.1111/1753-0407.12098

[9] Köhnke R, Mei J, Park M et al. Fatty acids and glucose in high concentration down-regulates ATP synthase beta-subunit protein expression in INS-1 cells. Nutr Neurosci 2007; 10: 273-278. doi:10.1080/10284150701745910

[10] Yang J, Chi Y, Burkhardt BR et al. Leucine metabolism in regulation of insulin secretion from pancreatic beta cells. Nutr Rev 2010; 68: 270-279. doi:10.1111/j.1753-4887.2010.00282.x

[11] Zhang CY, Parton LE, Ye CP et al. Genipin inhibits UCP2-mediated proton leak and acutely reverses obesity- and high glucose-induced beta cell dysfunction in isolated pancreatic islets. Cell Metab 2006; 3: 417-427. doi:10.1016/j.cmet.2006.04.010

[12] Geschwind JF, Hiriart M, Glennon MC et al. Selective activation of $\mathrm{Ca}^{2+}$ influx by extracellular ATP in a pancreatic beta-cell line (HIT). Biochim Biophys Acta 1989; 1012: 107-115. doi:10.1016/0167-4889(89)90018-9

[13] Pelegrin P, Surprenant A. Pannexin-1 mediates large pore formation and interleukin- $1 \beta$ release by the ATP-gated P2X7 receptor. EMBO J 2006; 25: 5071-5082. doi:10.1038/sj.emboj.7601378

[14] Orellana JA, Montero TD, von Bernhardi R. Astrocytes inhibit nitric oxide-dependent $\mathrm{Ca}(2+)$ dynamics in activated microglia: involvement of ATP released via pannexin 1 channels. Glia 2013; 61: 2023-2037. doi:10.1002/glia.22573

[15] Zhu L, Almaça J, Dadi PK et al. $\beta$-arrestin-2 is an essential regulator of pancreatic $\beta$-cell function under physiological and pathophysiological conditions. Nat Commun 2017; 8: 14295. doi:10.1038/ ncomms 14295

[16] Alejandro EU, Bozadjieva N, Blandino-Rosano M et al. Overexpression of kinase-dead mTOR impairs glucose homeostasis by regulating insulin secretion and not $\beta$-cell mass. Diabetes 2017; 66: 2150-2162. doi:10.2337/db16-1349

[17] Zhu Y, Xu G, Patel A et al. Cloning, expression, and initial characterization of a novel cytokine-like gene family. Genomics 2002; 80: 144-150. doi:10.1006/geno.2002.6816

[18] Wang C, Chi Y, Li J et al. FAM3A activates PI3K p110 $/$ Akt signaling to ameliorate hepatic gluconeogenesis and lipogenesis. Hepatology 2014; 59: 1779-1790. doi:10.1002/hep.26945

[19] Chen Z, Wang J, Yang W et al. FAM3A mediates PPARy's protection in liver ischemia-reperfusion injury by activating Akt survival pathway and repressing inflammation and oxidative stress. Oncotarget 2017; 8: 49882-49896. doi:10.18632/oncotarget.17805

[20] Song Q, Gou WL, Zhang R. FAM3A protects HT22 cells against hydrogen peroxide-induced oxidative stress through activation of PI3K/Akt but not MEK/ERK pathway. Cell Physiol Biochem 2015; 37 : 1431-1441. doi:10.1159/000438512

[21] Jia S, Chen Z, Li J et al. FAM3A promotes vascular smooth muscle cell proliferation and migration and exacerbates neointima formation in rat artery after balloon injury. J Mol Cell Cardiol 2014; 74: 173-182. doi:10.1016/j.yjmcc.2014.05.011

[22] Chi Y, Li ], Li N et al. FAM3A enhances adipogenesis of 3T3-L1 preadipocytes via activation of ATP-P2 receptor-Akt signaling pathway. Oncotarget 2017; 8: 45862-45873. doi:10.18632/ oncotarget. 17578 
[23] Ishihara H, Asano T, Tsukuda K et al. Pancreatic beta cell line MIN6 exhibits characteristics of glucose metabolism and glucose-stimulated insulin secretion similar to those of normal islets. Diabetologia 1993; 36: 1139-1145. doi:10.1007/BF00401058

[24] Yang W, Chi Y, Meng Y et al. FAM3A plays crucial roles in controlling PDX1 and insulin expressions in pancreatic beta cells. FASEB J 2020; 34: 3915-3931. doi:10.1096/fj.201902368RR

[25] Bradley SP, Rastellini C, da Costa MA et al. Gene silencing in the endocrine pancreas mediated by short-interfering RNA. Pancreas 2005; 31: 373-379. doi:10.1097/01.mpa.0000179730.69081.64

[26] Kapodistria K, Tsilibary EP, Kotsopoulou E et al. Liraglutide, a human glucagon-like peptide-1 analogue, stimulates AKT-dependent survival signalling and inhibits pancreatic beta-cell apoptosis. J Cell Mol Med 2018; 22: 2970-2980. doi:10.1111/jcmm.13259

[27] Wong JC, Vo V, Gorjala P, Fiscus RR. Pancreatic- $\beta$-cell survival and proliferation are promoted by protein kinase $G$ type l $\alpha$ and downstream regulation of AKT/FOXO1. Diab Vasc Dis Res 2017; 14: 434-449. doi:10.1177/1479164117713947

[28] Li JM, Wang W, Fan CY et al. Quercetin preserves $\beta$-cell mass and function in fructose-induced hyperinsulinemia through modulating pancreatic Akt/FoxO1 activation. Evid Based Complement Alternat Med 2013; 2013: 303902. doi:10.1155/2013/303902

[29] Wang Y, Wang H, Liu Y et al. Antihyperglycemic effect of ginsenoside Rh2 by inducing islet $\beta$-cell regeneration in mice. Horm Metab Res 2012; 44: 33-40. doi:10.1055/s-0031-1295416

[30] Li Z, Shangguan Z, Liu Y et al. Puerarin protects pancreatic $\beta$-cell survival via PI3K/Akt signaling pathway. J Mol Endocrinol 2014; 53: 71-79. doi:10.1530/JME-13-0302

[31] Bastidas-Ponce A, Roscioni SS, Burtscher I et al. Foxa2 and Pdx1 cooperatively regulate postnatal maturation of pancreatic $\beta$-cells. Mol Metab 2017; 6: 524-534. doi:10.1016/j.molmet.2017.03.007

[32] Kitamura T, Nakae J, Kitamura Y et al. The forkhead transcription factor FoxO1 links insulin signaling to $\mathrm{Pdx} 1$ regulation of pancreatic $\beta$ cell growth. J Clin Invest 2002; 110: 1839-1847. doi:10.1172/JCl16857

[33] Zhu P, Ma Z, Guo L et al. Short body length phenotype is compensated by the upregulation of nidogen family members in a deleterious nid1a mutation of zebrafish. J Genet Genomics 2017; 44: 553-556. doi:10.1016/j.jgg.2017.09.011
[34] Ma Z, Zhu P, Shi H et al. PTC-bearing mRNA elicits a genetic compensation response via Upf3a and COMPASS components. Nature 2019; 568: 259-263. doi:10.1038/s41586-019-1057-y

[35] El-Brolosy MA, Kontarakis Z, Rossi A et al. Genetic compensation triggered by mutant mRNA degradation. Nature 2019; 568: 193-197. doi:10.1038/s41586-019-1064-z

[36] Crooke ST, Witztum JL, Bennett CF et al. RNA-Targeted Therapeutics. Cell Metab 2018; 27: 714-739. doi:10.1016/j.cmet.2018.03.004

[37] Faas MM, Sáez T, de Vos P. Extracellular ATP and adenosine: The Yin and Yang in immune responses? Mol Aspects Med 2017; 55: 9-19. doi:10.1016/j.mam.2017.01.002

[38] Di Virgilio F, Sarti AC, Falzoni S et al. Extracellular ATP and P2 purinergic signalling in the tumour microenvironment. Nat Rev Cancer 2018; 18: 601-618. doi:10.1038/s41568-018-0037-0

[39] Emmett DS, Feranchak A, Kilic G et al. Characterization of ionotrophic purinergic receptors in hepatocytes. Hepatology 2008; 47: 698-705. doi:10.1002/hep.22035

[40] MacDonald PE, El-Kholy W, Riedel M] et al. The multiple actions of GLP-1 on the process of glucose-stimulated insulin secretion. Diabetes 2002; 51; Suppl 3: S434-S442. doi:10.2337/diabetes.51.2007.s434

[41] Yang J, Wong RK, Wang $X$ et al. Leucine culture reveals that ATP synthase functions as a fuel sensor in pancreatic $\beta$-cells. J Biol Chem 2004; 279: 53915-53923. doi:10.1074/jbc.M405309200

[42] Tang S, Xin Y, Yang M et al. Osteoprotegerin promotes islet $\beta$ cell proliferation in intrauterine growth retardation rats through the PI3K/ AKT/FoxO1 pathway. Int J Clin Exp Pathol 2019; 12: 2324-2338

[43] Ahlgren $U$, Jonsson J, Edlund $H$. The morphogenesis of the pancreatic mesenchyme is uncoupled from that of the pancreatic epithelium in IPF1/PDX1-deficient mice. Development 1996; 122: 1409-1416

[44] Horiguchi M, Yoshida M, Hirata K et al. Senescence caused by inactivation of the homeodomain transcription factor Pdx1 in adult pancreatic acinar cells in mice. FEBS Lett 2019; 593: 2226-2234. doi:10.1002/1873-3468.13504 